\title{
СЕРЦЕВА НЕДОСТАТНІСТЬ: МІСЦЕ БІОМАРКЕРІВ NT-proBNP TA SST 2
}

\author{
К.мед.н. Івчина Н. А. \\ Україна, м. Дніпро, Державний заклад «Дніпропетровська медична академія МОЗ \\ Украӥни», кафедра внутрішньої медичини 3
}

\section{DOI: https://doi.org/10.31435/rsglobal_ws/31082019/6636}

\begin{abstract}
ARTICLE INFO
Received: 18 June 2019

Accepted: 25 August 2019

Published: 31 August 2019

\section{KEYWORDS}

chronic heart failure, biomarkers, natriuretic peptide, NT-proBNP, ST2 receptor, prognosis, risk stratification, diagnosis, treatment.

ABSTRACT

Heart failure is the most common disease in recent decades. Optimizing the diagnosis and prognosis of various types of heart failure is an important task of modern medicine. The use of specific biomarkers to determine the diagnosis of heart failure, prognosis of the disease is an acute problem. To date, known biomarkers are natriuretic peptides and ST2 and its isoforms. These are highly sensitive biomarkers that allow you to personalize the risk of complications in a patient with heart failure. The article discusses both the single, single use of individual biomarkers, as well as the serial identification and combination of biomarkers to evaluate the prognosis.
\end{abstract}

Citation: Івчина Н. А. (2019) Sertseva Nedostatnist: Mistse Biomarkeriv NT-proBNP ta sST 2. World Science. 8(48), Vol.2. doi: 10.31435/rsglobal_ws/31082019/6636

Copyright: (C) 2019 Івчина Н. A. This is an open-access article distributed under the terms of the Creative Commons Attribution License (CC BY). The use, distribution or reproduction in other forums is permitted, provided the original author(s) or licensor are credited and that the original publication in this journal is cited, in accordance with accepted academic practice. No use, distribution or reproduction is permitted which does not comply with these terms.

Актуальність проблеми хронічної серцевої недостатності $(\mathrm{XCH})$ для лікарів багатьох країн залишається на провідних позиціях та обумовлена розповсюдженістю патології та значимими економічними втратами - важкість перебігу захворювання, потреба у госпіталізаціях та значним рівнем смертності. Мета лікування пацієнта 3 ХCH - підвищення ефективності лікування, покращення якості та тривалості життя, зниження смертності від ускладнень. Прогноз хворих на ХСН залежить від ряду умов та обставин. Це прихільність до лікування, прийом ліків, які погіршують перебіг ХСН (нестероїдні протизапальні препарати та ін..), гострий початок хвороби (гострий коронарний синдром (ГКС)), супутні захворювання (цукровий діабет (ЦД), хронічні обструктивні захворювання легень (ХОЗЛ), артеріальна гіпертензія (АГ)), наявність порушення ритму та ін.. Ці фактори можуть приводити до погіршення перебігу захворювання, повторних госпіталізацій через декомпенсацію ХСН та ін. [1]

Як відомо, для вказівки типу серцевої недостатності $(\mathrm{CH})$ використовується клінічний розподіл пацієнтів з СН на групи по фракції викиду для вказівки типу гемодинамічних порушень, що має важливе значення: недостатність зі зменшеною фракцією викиду лівого шлуночка $<40 \%$ вказує на систолічну дисфункцію; та серцева недостатність із збереженою фракцією викиду $\geq 50 \%$.

Симптоми та клінічні прояви ХCH на початковому та поступовому етапі неспецифічні, у деяких хворих на СН під час рутинного обстеження не вдається виявити більш-менш значимих відхилень. Встановлення діагнозу серцевої недостатності у хворих із збереженою фракцією викиду у безсимптомних пацієнтів представляє найбільшу складність, оскільки симптоми неспецифічні і можуть бути викликані декількома альтернативними внесерцевими станами, такими як хронічні захворювання легенів, анемія і хронічні захворювання нирок [2]

Тому як альтернативний та додатковий метод підтвердження діагнозу широко використовуються лабораторні методи діагностики. До типових відхилень від норми лабораторних показників у хворих на ХCH є анемія, гіпонатріємія, гіперкаліемія, підвищення 
рівнів трансаміназ, змінення показників рівнів гормонів щитовидної залози, коагулограмми та ін.. Але ці показники не мають прогностичних значень та не в повній мірі можуть відображати коректність проводимої терапії ХСН.

Для диференційної діагностики та прогнозування течії СН використовують альтернативні діагностичні підходи: специфічні біомаркери та інструментальні методи, що направлені на виявлення функціональних та структурних змін в міокарді.

Специфічні біомаркери (натрийуретические пептиди, розчинний ST2 рецептор, копептін, галектін-3 ) стали незамінними інструментами для діагностики, прогнозування та моніторингу різних серцево-судинних захворювань. Кількість біомаркерів, що вивчаються для використовування у діагностиці, мониторуванні та прогнозуванні течії СН дуже велика, однак в клінічній практиці представлені декілька, що доказали свою ефективність (натрийуретические пептиди, розчинний ST2 рецептор, копептін, галектін-3 )[3].

\section{Натрійуретичні пептиди.}

Зокрема це визначення концентрації в крові натрійуретичних гормонів (пептидів, НП) сімейство пептидів, що включає в себе передсердний натрійуретичний пептид (ANP), мозковий натрійуретичний пептид (BNP), а також пізніше ідентифіковані С-тип натрійуретичний пептид (CNP). Секреція НП підвищується при органічних ураженнях серці, а також при підвищенні гемодінамічної (об’ємної) нагрузки на серце. [4-6].

Значення натрійуретичних пептидів при ХCH домелено в багатьох міжнародних дослідженнях, у зв'язку з чим Свропейське товариство кардіологів рекомендує досліджувати вмісту натрійуретичних пептидів у крові при підозрі на ХCH та використовувати підвищення концентрації як критерій діагностики ХСН із збереженою фракцією викиду лівого шлуночка.

Вміст натрійуретичних гормонів також підвищується з віком, але може бути зниженим при наявності ожиріння та/або гіпотиріозу. Нормальне значення натрійуретичних гормонів без попереднього лікування майже виключає значиме ураження серця.

Сучасні технології дають можливість визначати усі форма НП. Але визначення підвищенної концентрації натрійуретичного пептіда (BNP) та N-термінального фрагмента мозкового натрійуретичного пропептида (NT-proBNP) має ряд перевог. А саме, пов'язане 3 гемодинамічним стресом [[7]]. Підвищення концентрації BNP є потужним незалежним маркером несприятливих результатів,смертності або повторної госпіталізації не тільки у хворих з СН, а також інших форм CC3. BNP i NT-proBNP знайшли широке застосування в сучасної практиці [8-9].

За даними клінічних досліджень є так звані порогові значення для НП. Для пацієнтів 3 гострим початком симптомів або різким прогресуванням для виключення СН рівень НП повинен бути нижче за 100 пг/мл, а його N-концевий попередник (NT-proBNP) - меньше 300 пг/мл. При поступовому початку симптомів рівень НП повинен бути меншим за 35 пг/мл, а NT-proBNP менший за 125 пг/мл. Слід зазначити, зо при поступовому розвитку симптомів СН чутливість тестів на НП та NT-proBNP меньша, ніж при гострому. Дані порогові значення можуть використовуватись при СН з будь-якою фракцією викиду лівого шлуночка [10].

Натрійуретичні пептиди більше 15 років «доказували» свою значимість та нарешті їх визначення $\epsilon$ частиною звичайного діагностичного процесу для пацієнтів 3 серцевою недостатністю, як при гострій, так і при хронічній серцевій недостатності. Тест на визначення натрійуретичного пептиду використовується в діагностиці та оцінки важкості ХСН на ранніх стаціях, для оцінки ризику та прогнозу із високою точністю. Однак натрійуретичні пептиди мають и ряд недоліків, а саме високу біологічну мінливість та вікову залежність. У людей похилого віку, пацієнтів 3 хронічною нирковою недостатністю (ХHH), гострим коронарним синдромом, дисфункцією правого шлуночка, легеневою гіпертензією та/ або емболією, анемією рівні натрійуретичного пептида будуть завищені. А в пацієнтів із в високим індексом маси тіла, гострим набряком легень, кардіоміопатією «Burmed-out», перікардитом рівні НП будуть занижені. Натрійуретіческій пептид має чутливість 70\% і специфічність 99\%, NT-proBNP має чутливість 99\% і 85\% специфічність для виявлення СН. Тест дозволяє знизити кількість помилкових результатів при використанні інших діагностичних методів, отже, сприяє підвищенню точності діагностики, прогнозу та стратифікації ризику при патології серця. [11-12]

\section{ST2 та його ізоформи.}

Важливу роль в біології міокарду при СН відіграє біомаркер ST2 - новітній маркер, який використовується в першу чергу для прогнозування і стратифікації ризику розвитку СН, 
випереджаючи значущість натрійуретічеських пептидів (HП, NT-proBNP). Крім цього, ST2 використовуєтся при прогнозуванні несприятливих наслідків і смерті пацієнтів 3 підтвердженим діагнозом $\mathrm{CH}$, а також прогнозувати розвиток серцево-судинних захворювань (СС3) в майбутньому в популяції в цілому.

ST2 - рецептор білкової природи, що належить до сімейств інтерлейкинів. ST2 зустрічаєтся в декілької ізоформах, включаючи трансмембранну форму (ST2 -ліганд, або ST2L) та розчинну, циркулуючу форму (sST2) $(9=$.). Ген ST2 високо експресується кардиомиоцитами i фібробластами при розтягуванні клітин [13].

Фізіологічна роль ST2 полягає в двох механізмах: діє як кардіопротектор (зворотній процес ремоделювання та гіпертрофії) та здійснює імунну відповідь на запалення. Теоретично протективна роль ST2 полягає в тому, що при перегрузці тиском підвищується синтез IL - 33, який в свою чергу механізм ліганд-рецепторної взаємодії з ST2L має захистну дію, що проявляється стримуванням процесів гіпертрофії та фіброзу міокарду [14].

В неушкодженому міокарді IL - 33, який продукується серцевими фібробластами, 3'язуєтся із ST2L, та цей комплекс активує ряд внутріклітинних сигнальних каскадів. При СН розчинний sST2, виміряємо ізоформа в сучасних тестах, як вважають, виступає в якості пастки - рецептора для IL - 33. Наявність високої концентрації sST2 блокує сприятливі ефекти IL - 33. Слідуючи 3 цього, високий рівень розчинного sST2 асоціюється із прогресуванням фіброзу міокарду, гіпертрофії міокарду, несприятливим ремоделюванням серця та серецево-судинними наслідками [15-16]

ST2 експресується в серці у відповідь на патологічні зміни, викликані хронічними захворюваннями i / або гострими ушкодженнями. Він відображає ремоделювання шлуночків $\mathrm{i}$ фіброз серця. SST2 дозволяє визначити величину ризику, виявити пацієнтів 3 високою вірогідністю розвитку несприятливих наслідків і своєчасно надати йому допомогу. На відміну від інших кардіомаркерів, рівень sST2 швидко змінюється у відповідь на лікування, його використання можливо при моніторингу та корекції терапії. У клінічній практиці у пацієнтів 3 хронічною серцевою недостатністю $\mathrm{sST} 2$ має порівняно прогностичну цінність, при використанні з натрійуретічними пептидами і однаково корисну для прогнозу у пацієнтів як 3 низькою, так і нормальною фракцією викиду [17]. Методика серійного вимірювання SST2 при хронічній серцевій недостатності містить істотну прогностичну інформацію, демонструючи чудові прогностичні характеристики в порівнянні з усіма іншими маркерами, включаючи тропонин, і NT-proBNP [18-19].

Середня концентрація sST2 - 18 нг/мл, рівень більший за 35 нг/мл є маркером відвищеного ризику серцево-судинної смерті. [20]

У рекомендаціях по клінічній практиці Американського коледжу кардіології / Американської асоціації серця (АСC / AHA) представлені рекомендації класу IIb для вимірювання SST2 при гострій декомпенсованій серцевій недостатності (рівень доказовості А) i хронічної серцевої недостатності (рівень доказовості В) 3 метою стратифікації ризику та прогнозування серцевої недостатності [21].

Більшість проведених досліджень базувались на прогностичній значущості разових базових вимірюваннях для оцінки несприятливого перебігу СН. Прогностична та предикторна цінність окремих вимірювань знайшла підтвердження у мета аналізі проведенних при ХСН та гострій СН [22-23]

За даними TRIUMF STUDY повторні визначення рівнів ST2 виявились сильними предикторами результатів у пацієнтів з гострою $\mathrm{CH}$, та представляють додаткову незалежну прогностичну інформацію до ісходного та серійного визначення NT-proBNP.

При XCH ST2 був пов'язаний із відносним ризиком (HR) смерті від усіх причин 1,75 и 1,79 для серцево-судинній смерті [15]. При гострій СН при госпіталізації ST 2 мав HR від серцево-судинній смерті 2,29 та при виписки 2,20.

Встановлено, що циркулуючий пул ST2 добре та позитивно асоціюється 3 величиною ризику кардіоваскулярної смерті в популяції пацієнтів гострої $\mathrm{CH}$ із дисфункцією міокарда Крім того, рівень SST 2 при виписки пацієнта є пре диктором повторної госпіталізації з приводу декомпенсації СН в продовж року [24]

Актуальність визначення та монінторування iST2 доведена також у пацієнтів х CH 3 -4/ або в термінальній стадії. Доведено, що sST2 має великий потенціал для своєчасного прийняття 
рішення про використання неінвазивних методів лікування, аж до трансплантації. В останніх дослідженнях відзначений зв'язок sST2 з гострим клітковим відторгненням трансплантованого серця, а також із прогнозуванням смертності у віддаленому періоді. [25]

Проте, при всій високій діагностичній цінності sST2 не слід забувати, що його підвищення також зустрічається і при ряді інших захворювань, таких як гострі і хронічні запальні, аутоімунні захворювання і бронхіальна астма та інше.

Ряд авторів висловлює пропозицію про ефективність використання багатомаркерних стратегій в моніторингу серцево-судинних захворювань, яка здатна більш точно відображати ключові ланки патогенезу i перебігу захворювання у кожного пацієнта індивідуально. Підвищення в сироватці крові рівнів NT-proBNP та ST2 у пацієнтів з серцевою недостатністю і систолічною дисфункцією лівого шлуночка дозволяє збільшити прогностичну значимість дослідження [26-28].

Нещодавно розроблений он-лайн калькулятор підрахунку ризику СН - Барселона bioHF, який включає ST-2 разом із NT-proBNP та високочутливим тропоніном T (hs-TnT) для розрахунку ризику смерті та/або госпіталізації в продовж 5 років [29].

Таким чином, на сьогоднішній день ми маємо загальновизнані біомаркерами, що входять в рекомендації з ведення хворих з СH (BNP та NT-proBNP) та «молоді» біомаркери, що продовжують доказувати свою цінність (sST2), як поодинці, так і в сукупності один з одним. Вони можуть і повинні застосовуватися сімейними лікарями і кардіологами в реальній клінічній практиці. Для підтвердження наявності СН та прогнозування перебігу, скорочення затрат на лікування та попередження ускладнень $\mathrm{CH}$ в майбутньому необхідне проведення додаткових досліджень.

\section{ЛIТЕРАТУРА}

1. Ponikowski P. et al. 2016 ESC Guidelines for the diagnosis and treatment of acute and chronic heart failure: The Task Force for the diagnosis and treatment of acute and chronic heart failure of the European Society of Cardiology (ESC). Developed with the special contribution of the Heart Failure Association (HFA) of the ESC. Eur. J. Heart Fail. 2016; 18(8): 891-975

2. Svennberg E., Lindahl B., Berglund L. et al. NT-proBNP is a powerful predictor for incident atrial fibrillation — validation of a multimarker approach. Int J Cardiol. 2016; 223: 74-81

3. Billebeau G., Vodovar N. et al. Effects of a cardiac rehabilitation programme on plasma cardiac biomarkers in patients with chronic heart failure. Cohen-Solal A. Eur J Prev Cardiol. 2017; 24(11): 1127-1135.

4. Ewald B, Ewald D, Thakkinstian A, Attia J. Meta-analysis of B type natriuretic peptide and N-terminal pro B natriuretic peptide in the diagnosis of clinical heart failure and population screening for left ventricular systolic dysfunction. Internal Medicine Journal. 2008;38 (2):101-13. DOI:10.1111 / j. 1445-5994.2007.01454. x

5. Doust JA, Glasziou PP, Pietrzak E, Dobson AJ. A Systematic Review of the Diagnostic Accuracy of Natriuretic Peptides for Heart Failure. Archives of Internal Medicine. 2004;164(18):1978. DOI:10.1001 / archinte. 164.18.1978

6. Zaphiriou A, Robb S, Murray-Thomas T, Mendez G, Fox K, McDonagh T et al. The diagnostic accuracy of plasma BNP and NTproBNP in patients referred from primary care with suspected heart failure: Results of the UK natriuretic peptide study. European Journal of Heart Failure. 2005;7(4):537-41. DOI:10.1016 / j. ejheart. 2005.01.022

7. Januzzi JL, Peacock WF, Maisel AS, Chae CU, Jesse RL,Baggish AL et al. Measurement of the interleukin family member ST2 in patients with acute dyspnea: Results from the PRIDE (Pro-Brain Natriuretic Peptide Investigation of Dyspnea in the Emergency Department) study. J Am Coll Cardiol. 2007; 50 (7): 607-613.

8. Chen LQ, de Lemos JA, Das SR, Ayers CR, Rohatgi A. Soluble ST2 is associated with all-cause and cardiovascular mortality in a population-based cohort: The Dallas Heart Study. Clin Chem. 2013; 59: 536-546.

9. Van Kimmenade RR, Pinto YM, Bayes-Genis A, Lainchbury JG, Richards AM, Januzzi JLJr. Usefulness of intermediate aminoterminal pro-brain natriuretic peptide concentration for diagnosis and prognosis of acute heart failure. Am J Cardiol. 2006; 98: 386-390.

10. Richards A.M. The relationship of plasma NT-proBNP to age and outcomes in heart failure. JACC Heart Fail. 2016; 4(9): 746-748.

11. Yancy CW, Jessup M, Bozkurt B, et al. 2017 ACC/ AHA/HFSA Focused Update of the 2013 ACCF/AHA Guideline for the Management of Heart Failure:a report of the American College of Cardiology/ American Heart Association Task Force on Clinical Practice Guidelines and the Heart Failure Society of America. J Am Coll Cardiol 2017;70:776-803.

12. Ponikowski P, Voors AA, Anker SD, et al. 2016 ESC guidelines for the diagnosis and treatment of acute and chronic heart failure: the task force for the diagnosis and treatment of acute and chronic heart failure of 
the European Society of cardiology (ESC). Developed with the special contribution of the Heart Failure Association (HFA) of the ESC. Eur J Heart Fail 2016;18:891-975.

13. Pascual-Figal DA, Garrido IP, Blanco R, Minguela A, Lax A, Ordonez-Llanos J et al. Soluble ST2 is a marker for acute cardiac allograft rejection. Ann Sur Thorac.2011; 92 (6): 2118-2124.

14. May Khal A., Ky B. Defining the Role of ST2: A Multimarker Approach?// J Card Fail.2012; 18 (4):311-312

15. Daniels LB, Bayés Genís A. Using ST2 in cardiovascular patients: a review. Future Cardiol 2014;10:525-39.

16. 16 .Bayés - Genís A, Januzzi JL, Gaggin HK, et al. ST2 pathogenetic profile in ambulatory heart failure

17. Januzzi JL, Horne BD, Moore SA, Galenko O, Snow GL, Brunisholz KD et al. Interleukin receptor family member ST2 concentrations in patients following heart transplantation. Biomarkers. 2013; 18 (3): 250-256.

18. Baba Y, Maeda K, Yashiro T, Inage E, Kasakura K, Suzuki R et al. GATA2 is a critical transactivator for the human IL1RL1/ST2 promoter in mast cells/basophils: Opposing roles for GATA2 and GATA1 in human IL-1RL1/ST2 gene expression. J Biol Chem. 2012; 287 (39): 32 689-32 696.

19. Ho JE, Chen WY, Chen MH, Larson MG, McCabe EL, Cheng S et al. Common genetic variation at the IL1RL1 locus regulates IL-33/ST2 signaling. J Clin Invest. 2013; 123 (10): 4208-4218.

20. Moliner P. Bayes-Genis A. et al Bio-profiling and bio-prognostication of chronic heart failure with midrange ejection fraction. Int J Cardiol. 2018; 257: 188-192

21. Рекомендации ESC по диагностике и лечению острой и хронической сердечной недостаточности 2016. Рабочая группа по диагностике и лечению острой и хронической сердечной недостаточности Европейского общества кардиологов (ESC) при участии Ассоциации сердечной недостаточности (АCH) в составе ESC. Российский кардиологический журнал. 2017; 1(141): 7-81.

22. Aimo A, Vergaro G, Ripoli A, et al. Meta-analysis of soluble suppression of tumorigenicity-2 and prognosis in acute heart failure. J Am Coll Cardiol HF 2017;5:287-96.

23. Aimo A, Vergaro G, Passino C, et al. Prognostic value of soluble suppression of tumorigenicity - 2 in chronic heart failure: a meta- analysis. A Am Coll Cardiol HF 2017;5:280-6

24. Socrates et al. Interleukin family member ST2 fyl mortality in acute dyspnoea. L.Int Med 2010; 268: 493-500

25. Januzzi JL, Horne BD, Moore SA, Galenko O, Snow GL, Brunisholz KD et al. Interleukin receptor family member ST2 concentrations in patients following heart transplantation. Biomarkers. 2013; 18 (3): 250-256.

26. Sabatine MS, Morrow DA, Higgins LJ, MacGillivray C,Guo W, Bode Ch et al. Complementary roles for biomarkers of biomechanical strain ST2 and N-terminal prohormone B-type natriuretic peptide in patients with ST-elevation myocardial infarction. Circulation. 2008;117 (15): 1936-1944.

27. Boisot S, Beede J, Isakson S, Chiu A, Clopton P, Januzzi J et al. Serial sampling of ST2 predicts 90-day mortality following destabilized HF. J Card Fail. 2008; 14 (9): 732-738.

28. Pascual-Figal DA, Manzano-Fernandez S, Boronat M, Casas T, Garrido IP, Bonaque JC et al. Soluble ST2, high-sensitivity troponin $\mathrm{T}$ - and $\mathrm{N}$-terminal pro-B-type natriuretic peptide: Complementary role for risk stratification in acutely decompensated heart failure. Eur JHeart Fail. 2011; 13: 718-725.

29. Lupon J, de Antonio M, Vila J, et al. Development of a novel heart failure risk tool: the Barcelona bio-heart failure risk calculator (BCN bio-HF calculator). PLoS ONE 2014;9:e85466 